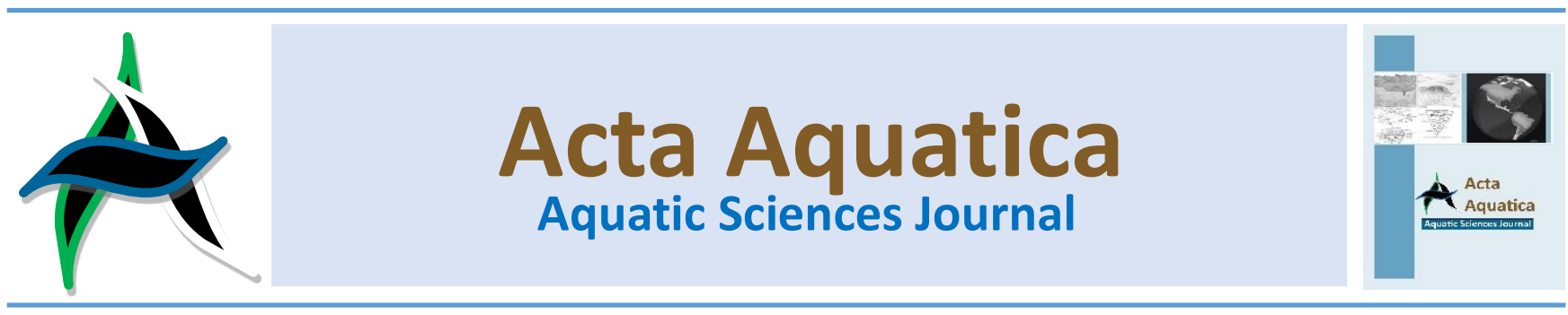

\title{
The efficacy of sodium chloride application in the control of fish lice (Argulus sp) infection on tilapia (Oreochromis niloticus)
}

\author{
Rita Rosmala Dewi ${ }^{a, b}{ }^{*}$, Wordianti Siallagan ${ }^{b}$ and Dwi Suryanto ${ }^{c}$ \\ ${ }^{a}$ Department of Animal Science, Faculty of Agriculture, Tjut Nyak Dhien University \\ ${ }^{b}$ Department of Water Resource Management, Faculty of Agriculture, Universitas Sumatera Utara \\ 'Department of Biology, Faculty of Mathematics and Natural Sciences, Universitas Sumatera Utara
}

\begin{abstract}
The Argulus sp infection in freshwater fish including tilapia (Oreochromis niloticus) causes the serious problem in aquaculture. Despite the scarce of the preventive action in parasite infection, the application of salt mostly have been done in fish farming to overcome these parasites. The sodium chloride $(\mathrm{NaCl})$ was used in farm because it was safe for water environment as well as its economic advantage. The effectiveness of sodium chloride to control ectoparasites Argulus sp in tilapia juvenile was tested in laboratory. The fishes were infected by Argulus sp. and they are treated short term dip with three doses of sodium chloride namely $3 \mathrm{ppm}, 6 \mathrm{ppm}$ and $9 \mathrm{ppm}$ for ten days. The prevalence of parasites, the parasites intensity, and survival rate were examined and the results were evaluated using statistic. The result showed that the $\mathrm{NaCl}$ salt application significantly affected the prevalence, the parasite intensity and the survival rate of fishes. The best dose that give the lowest prevalence, the lowest parasite intensity and the highest survival rate was the G3 (9 ppm dose).
\end{abstract}

Keywords: Argulus sp; Oreochromis niloticus; sodium chloride; prevalence; intensity; survival rate

\section{Introduction}

The parasites infection restraint aquaculture industry since it caused a great loss economic implication and mortality. It also could reduces fish performance such as scale loss, colour change and many pathological aspects then it will affect the market demand. Obviously, parasites possibly have the capability to directly lessen the appearance of their hosts, in terms of growth and reproduction, through their direct impact on fish health (Barber, 2007). The high mortality rate due to the damages in organ of reproduction (Al Jahdali and El Shassanine, 2010) and secondary infection by bacterial diseases (Densmore et al., 2004).

Argulosis caused by fish louse (Argulus sp) is the main parasitic problem that could be found in Indonesia both wild fish and farm (Muchlisin et al., 2014). Fish louse is the ordinary name for ectoparasites of branchiurid that infected fish from the genus Argulus (Noga, 2002). Argulus feed by sucking blood from their host using their stylet and it makes iritation on the fish body surface (Noga, 2002). Their feeding and attachment activities can lead the alterations of organ and tissue (including loss of blood) and osmoregulations problems, as well as transmit the pathogen

\footnotetext{
* Corresponding author: Department of Animal Science, Faculty of Agriculture, Tjut Nyak Dhien University. Medan. North Sumatera Provice, 20123. Indonesia. Tel: +061-8451508.

e-mail: ritardewi@yahoo.com

doi: https://doi.org/10.29103/aa.v5i1.584
}

such as viruses, bacteria, blood-born protozoa, and nematodes (Rameshkumar and Ravichandran, 2014). Buccal cavity of fish become the sites of several argulus infection, others exist in the gill chamber or on the body surface including the fins (Rameshkumar and Ravichandran, 2014).

Argulosis has a direct life cycle and the stage that the Argulus sp hatches from the egg is immediately became parasite (Woo, 1995). Argulus generally attaches to the host and develops into maturation on it. Both adult and juvenile of Tilapia fish is vulnerable to ectoparasites infection since they are cultured in high density population with poor water quality and stress condition.

Insecticides has been used for long time period to control the argulus infection in fish culture such as emamectin benzoat, pottasium permanganat, formalin (Hakalahti, et al., 2004) and organophosphate (Noga, 2002). Thought, insecticides is highly toxic to human and fishes as well as chemical antiparasitic agent and also could not easily degrade in the environment (Woo, 1995). Besides that, the insecticides resistancy was developed by parasites fairly quickly (Kabata, 1985). As well as inceticides, malachite green that is used in aquaculture is banned in many countries because of their highly toxic effect.

As a result, environmental friendly agents are developed to replace the hazardous chemical as an antiparasitic agents in aquaculture. Sodium chloride is antiparasite agents that widely use in fish farm to control parasites including Argulids (Kabata, 1985). Since Argulus sp is ectoparasites that infest fish external body, the sodium chloride application by bath is effective to control argulosis in fish. The efficacy of sodium chloride to 
combat parasite Argulus sp in juvenile of tilapia was examined by challenging the parasites with juvenile fish that treated with salt in their water media. Then, the prevalence, parasites intensity and survival rate of fish was examined, as well as the corellation between dose of salt was evaluated by using statistic.

\section{Materials and methods}

\subsection{Argulus sp preparation}

Argulus sp was collected from fish that infected by argulosis from fish farm in Medan Agriculture and Fisheries Services. Argulids infected fish was cultured in tank that had poor water quality condition so that suitable for reproducing Argulus $\mathrm{sp}$ for experiment. The water quality manipulation have done by overfeeding methods then the poor water parameters would make fish stress and Argulus sp multiply rapidly. It has done for 36 days to gain the expected number of Argulus sp that was about 240 parasites.

\subsection{Media and fish adaptation preparation}

Aquarium as an experiment media should be washed, desinfected and dried for 24 hours. Then, it was filled with 12 litres of freshwater and it was aerated by aerator for 48 hours. The number juvenile of tilapia that was acclimatization in the aquarium for three days contained 5 fishes per each aquarium.

\subsection{Laboratory experiment and data analysis}

The efficacy of sodium chloride in prevention and control of argulosis was tested under laboratory conditions at a fish farm in Medan. Each aquarium both control and medicated, contained 5 healthy fishes. The experimental challenge of sodium chloride with fish louse was repeated 3 times using different doses namely $36 \mathrm{gram} / \mathrm{L}, 72 \mathrm{gram} / \mathrm{L}$ and $108 \mathrm{gram} / \mathrm{L}$. After one hour acclimatization, 20 parasites Argulus sp was released to each aquarium. During 10 days challenge periods, the parasites prevalence, the parasites intensity and fish mortality were examined and calculated. The parasites

Prevalence was calculated using formula by Kabata (1985) as follow: Prevalence $(\%)=(\Sigma$ infected fish $/ \Sigma$ examined fish) $\times 100 \%$, while the intensity was calculated using the formula as follow: Intensity $=\Sigma$ parasites found $/ \Sigma$ infected fish. Then the survival rate was calculated using the formula: Survival Rate (\%) $=(\Sigma$ live fish $/ \Sigma$ examined fish $) \times 100 \%$. The effectiveness of sodium chloride dose was analyzed with ANOVA and with $F$ test to know the affect of each test to parameters.

\subsection{Water quality examination}

The water quality mantain in the good state so that the stress of experimental fish in this experiment was avoided. The water quality parameters that examined in this experiment were temperature, $\mathrm{pH}$ and dissolve oxygen.

\section{Result and discussion}

\subsection{Result}

\subsubsection{Parasite infestation found on tilapia}

The prevalence of parasite Argulus sp in control fish showed the highest number $(88 \%)$ rather than fish treated with sodium chloride (Figure 1). The fish that treated with $3 \mathrm{ppm}$ sodium chloride had the highest prevalence of Argulids infection with $73.83 \%$, on the other hand the lowest prevalence rate was found on $9 \mathrm{ppm}$ dose of sodium chloride with $37.33 \%$. It decreased by half compared to $3 \mathrm{ppm}$ treatment. Then, the parasite prevalence in the control fish could reach $60 \%$ in the first day of infection and rise gradually up to $100 \%$ at the end of the examination (Figure 2). On the other hand, the treatment fish showed the delayed of infestation although there were also the gradual slightly increasing in mortality in ten days infection. Based on statistic analysis, all the treatments were significantly different from control fish (G0).

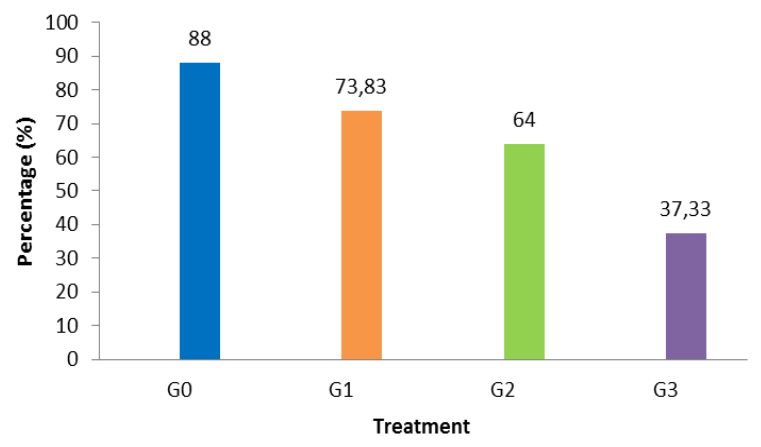

Figure 1. The prevalence of Argulus sp infestation on tilapia.

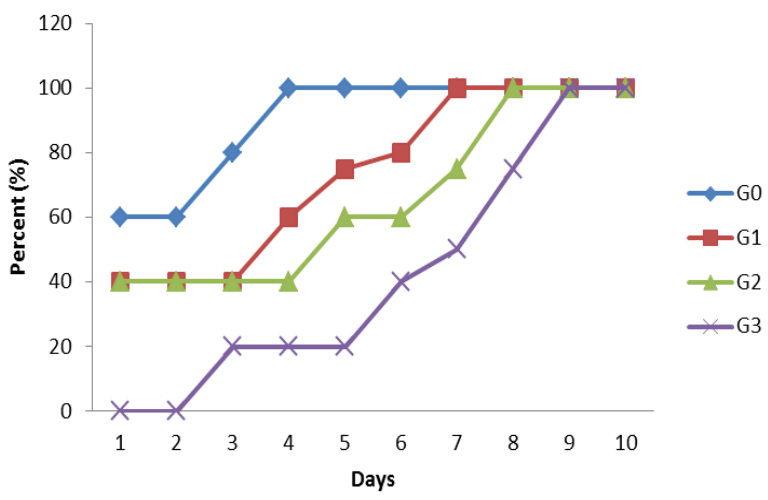

Figure 2. The prevalence of Argulus sp infestation on tilapia.

\subsubsection{Parasite population found at laboratory trial}

The number of parasites that infect fishes defined as parasites intensity and it represents in Figure 2. The chart showed the trend of parasites number that infect fish for ten days. Control fish (G0), and treatment fish, both 3 ppm salt (G1) and $6 \mathrm{ppm}(\mathrm{G} 2)$ respectively, showed the highest number of in the first day about $6.3,8.5$ and 8.2 , respectively the number of parasites in control fish (G0) decreased gradually for 5 days, while treatment fish $\mathrm{G} 1$ was fluctuated rise and fish $\mathrm{G} 2$ was gradually fell. However, after the sixth day, parasites population in fish control rose significantly leaved the treatment $\mathrm{G} 1$ in the second place. The treatment 9 ppm (G3) showed different trend in parasites intensity for 10 days. The number of parasites reached the highest number in the second days about 6 , then it was gradually fell for eight days. Based on statistically analysis, the result showed that the control $(\mathrm{G} 0)$ is significantly different from the treatment ( $\mathrm{G} 2$ and $\mathrm{G} 3$ ) on the parasite intensity. 


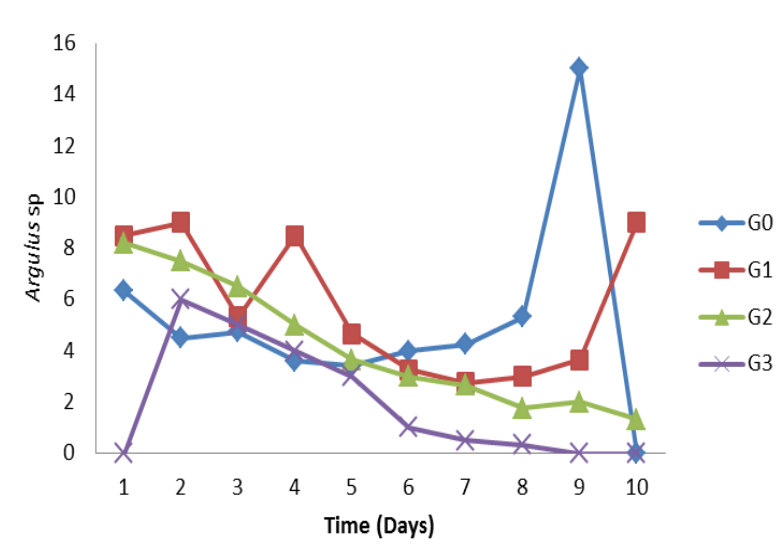

Figure 3. The Intensity number of parasite Argulus sp

\subsubsection{Survival rate of tilapia}

Parasite infestation in fish caused mortality due to their capability to make any damages in the host organ. In this study, the survival rate of fish will be examined to know the effectiveness of natrium chloride to reduce the mortality rate (Figure 4). The number of live fishes mantain in $100 \%$ until the fourth days for both control and treatment fishes. Then, the survival rate in control fishes was fell significantly about $20 \%$ in the tenth day, while the treatment fish with $9 \mathrm{ppm}$ sodium chloride (G3) decreased slightly about $73.3 \%$. Based on statistically analysis, the result showed that the control (G0) is significantly different from the treatment ( $G 2$ and $G 3$ ) on the fih survival rate.

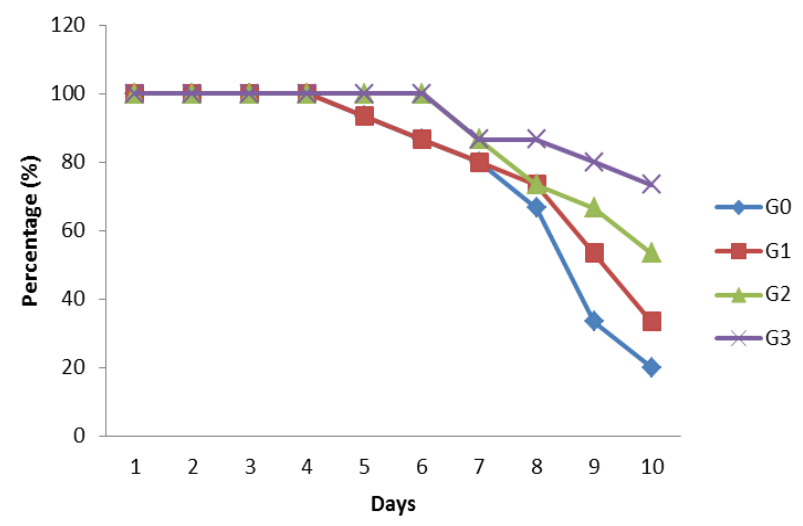

Figure 4. The survival rate of tilapia.

\subsubsection{Location of fish organ infected by parasites and clinical sign}

The external examination of infected fishes showed that Argulus sp live in head, flank and fin of the fish (Table 1).

Table 1.

Parasite intensity on different fish body location.

\begin{tabular}{lccc}
\hline \multirow{2}{*}{ Treatment } & \multicolumn{3}{c}{ Argulus sp infestation on fish body location } \\
\cline { 2 - 4 } & Head & Flank & Fin \\
\hline G0 & 2,4 & 4,3 & 3,5 \\
G1 & 2,1 & 4,1 & 3,2 \\
G2 & 1,8 & 3,7 & 3,1 \\
G3 & 1,2 & 2,0 & 1,2 \\
\hline Avarage & 1,87 & 3,52 & 2,75 \\
\hline
\end{tabular}

The highest parasites intensity were on flank about 3.52, while the head had the lowest parasites population about 1.87 . The parasites infestation in fish body caused the clinical sign of argulosis in juvenile fish (Figure 5). The early symptom were swimming abnormality, the fish rubbing themselves into aquarium wall and hipersecretion mucus. Then, there are haemmorrhage and lession in the body that infected by parasites.

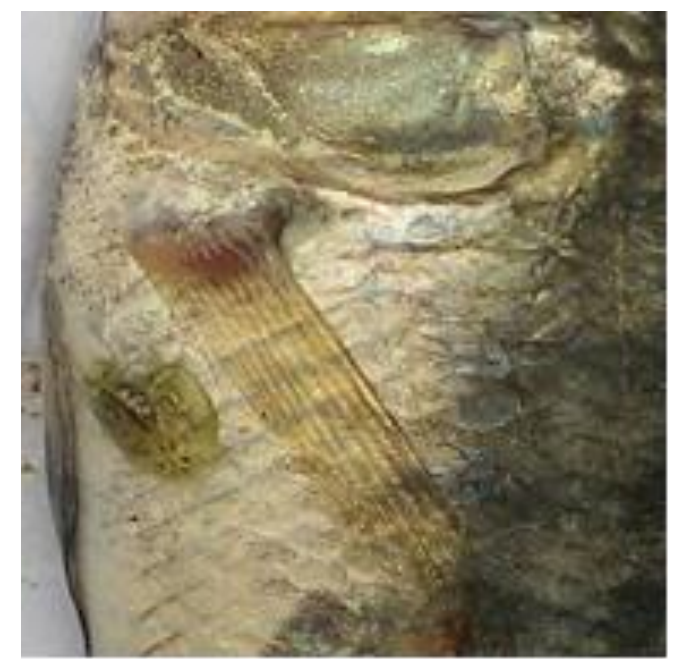

Figure 5. The parasite Argulus sp infected the body of fish.

\subsubsection{Water quality parameters}

The parameters of water quality in the aquarium were measured during the biology assay to mantain the fish condition (Table 2). The avarage temperature of water for all the aquarium were $27.32-27.1^{\circ} \mathrm{C}$. The water $\mathrm{pH}$ values were around $7.95-8.25$, then for dissolved oxygen in the aquarium were $6.42-7.93 \mathrm{ppm}$.

\subsection{Discussion}

Argulus infection in fish farm can form a serious threat to fish population in many part of the world and ecosystem because their ability to adapt in different type of aquatic ecosystem, and there are species adapted to extremes of temperature, pressure, salinity, and even anoxia (Rameshkumar and Ravichandran, 2014). Argulus sp infected the wide range of the host (Woo, 1995) including Goldfish (Wafer et al., 2015), Mahseer fish (Tor tambra Valenciennes, 1842) (Muchlisin et al., 2015) and Tilapia fish (Webb, 2008). The infection of Argulus sp in tilapia farm affect the farmer because it cause the morbidity as well as mortality.

The Argulus sp could infested juvenile fish as they contact in the water as shown in this study that the prevalence of parasites in the control aquarium reach the high prevalence number as well as low sodium chloride application. After hatching from egg, Argulus sp is immediatelly parasitic and attaches to the host on which it will mature (Woo, 1995). The prevalence rose significantly up till the tenth days both control and low natrium chloride concentration however the highest sodium chloride concentration give the lowest prevalence and shown the best performance according to statistic analysis. The prevalence of Argulus sp in many fish have been already reported including carp varied among the sampled localities, about $6.3 \%$ to $38.5 \%$ and Pike-perch was very high, about $80 \%$ to $100 \%$ in the sampled localities (Aalberg et al., 2016).

The Intensity of parasite treated with the highest concentration of sodium chloride showed the lowest number during the examination. Based on the intensity number and the prevalence, sodium chloride $9 \mathrm{ppm}$ dose could inhibit the parasite attachment to the tilapia juvenile in the early days of 
infection. Sodium chloride application could reduced patogenicity of the argulus for several day. This result along with the Magondu et al. (2011) that state that sodium chloride is appropriate to use in pathogen treatmnet in catfish. Nevertheless it was not along with Siren (2008) that state all the life cycle stage of Argulus could not affected by sodium chloride. The sodium chloride application could reduce the mortality then mantain the high survival rate of the juvenile that infected by Argulus sp for early days of infection. After the fourth day, there were the mortality in control and low dose of sodium chloride fish. On the other hand, highest dose of sodium chloride give more protection for fish that attacked by Argulus sp that is showed by highest survival rate. Salt could improve the osmoregulation of fish and probably inhibit the mature Argulus $s p$ that was used in this study.

The clinical signs that showed in infected tilapia were swimming abnormality, the fish rubbing themselves into aquarium wall and hipersecretion mucus. Then, there are haemmorrhage and lession in the body that infected by parasites. It was along with the study of clinical sign in carasius auratus (Al Darwesh et al., 2014). The preference of fish body by Argulus sp in this study were head, two side of body and fin were the and it is accordance with work of Muchlisin et al. (2014).

\section{Conclusion}

The prolonged medication of sodium chloride affect the Argulus sp infestation in tilapia juvenile fish. The best performance was exhibited by the highest dose $(9 \mathrm{ppm})$ could mantain the survival rate and reduce the prevalence and parasite intensity of Argulus sp that attack the tilapia juvenile. The mechanism of sodium chloride in inhibiting the parasite Argulus $\mathrm{sp}$ and its aplication in the field should be done for the future work.

\section{Bibliografi}

Aalberg, K., Koščová, L., Šmiga, L'., Košuth, P.Koščo, J., Oros, M., Barčák, D., Lazar, P., 2016. A Study Of Fish Lice (Argulus Sp.) Infection In Freshwater Food Fish. Folia Veterinaria, 60(3): 54-59.

Al Darwesh, A.A., Al Shabbani, M.A.A., Faris, B.H., 2014. Diagnostic and pathological study of Argulus japonicasin goldfish (Carassius auratus) , G.J.B.B.3 (4): 384-387.

Al-Jahdali, M.O., R.M. El-Shassanine. 2010. Ovarian abnormality in a pathological case caused by Myxidium sp. (Myxozoa, Myxosporea) in onespot snapper fish Lutjanus monostigma (Teleostei, Lutjanidae) from the Red Sea. Acta Para. 55:1-7.

Barber, I., 2007. Parasites, Behaviour and Welfare in Fish. Applied Animal Behaviour Science 104 : 251-264.

Densmore, C. L., C. A. Ottinger, V. S. Blazer, L. R. Iwanowicz, D. R. Smith. 2004. Immunomodulation and disease resistance in postyearling rainbow trout infected with Myxobolus cerebralis, the causative agent of whirling disease. J. of Aquatic Animal Health 16:73-82.

Hakalahti, T., Lankinen, $\mathrm{Y}$ and Valtonen, E.T., 2004. Efficacy of emamectin benzoate in the control of Argulus coregoni (Crustacea: Branchiura) on rainbow trout Oncorhynchus mykiss. 6 : 197-204.
Kabata, Z., 1985. Parasites and diseases of fish cultured in the tropics. Taylor \& Francis. London.

Magondu, E.W., Rasowo, J., Okoth, E.O., Charo-Karisa, H., 2011. Evaluation of sodium chloride $(\mathrm{NaCl})$ for potential prophylactic treatment and its short-term toxicity to African catfish Clarias gariepinus (Burchell 1822) yolk-sac and swim-up fry. Aquaculture, 319 307-310.

Muchlisin, Z.A., Munazir, A.M., Fuady, Z., Winaruddin, W., Sugianto,S., Adlim, M., Fadli, N., Hendri, A., 2014. Prevalence of ectoparasites on mahseer fish (Tortambra Valenciennes, 1842) from aquaculture ponds and wild population of Nagan Raya District, Indonesia. HVM Bioflux 6(3):148-152.

Noga. 2000. Fish Diseases; Diagnosis and Treatment. lowa State Press. A Blackwell. United State pp. 85-90.

Rameshkumar, G., Ravichandran, S., 2014. Problems caused by isopod parasites in commercial fishes. I Parasit Dis 38(1):138-141.

Sirén,T.H., Mikheev, V.N., Valtonen, E.T., 2008. Control of freshwater fish louse Argulus coregoni: a step towards an integrated management strategy. Dis Aquat Org. 82 : 6777.

Wafer, L.N., Whitney, J.C., Jensen, V.B., 2015. Fish Lice (Argulus japonicus) in Goldfish (Carassius auratus). Comparative Medicine. 65 (2).

Webb, A.C., 2008. Spatial and Temporal Influences On Population Dynamics Of A Branchiuran Ectoparasite, Argulus Sp. , In Fresh Waters Of Tropical Northern Queensland, Australia. Crustaceana 81 (9).

Woo, P.T.K., 1995. Fish Diseases and Disorders : Protozoan and Metazoan Infections. CAB International. pp. 542-550. 